\title{
Corporate Social Responsibility as a Tool for Sustainable Development
}

\author{
L. I. Minnegaliyeva ${ }^{1, *}$, E. V. Elfimova ${ }^{1}$, A. V. Goloviznin ${ }^{1}$, R. Yu. Mamedov² \\ ${ }^{1}$ Ural State University of Economics, Yekaterinburg, Russia \\ ${ }^{2}$ Academy of Police of the Ministry of Internal Affairs of the Republic of Azerbaijan, Baku, Azerbaijan Republic \\ ${ }^{*}$ Corresponding author. E-mail: larissa5@mail.ru.
}

\begin{abstract}
The article considers corporate social responsibility as an instrument of sustainable development. The authors disclose the concept of corporate social responsibility, describe in detail its main areas. The main causes of accidents at work are analyzed, with statistics on the emerging downward trend of victims. Particular attention is paid to the legislation of the Russian Federation, which is in the process of forming certain directions of sustainable development. The problem of discrimination against the rights of workers is revealed and a comprehensive approach is proposed to address this issue. Finally, the conclusion that sustainable development is directly dependent on corporate social responsibility is justified.
\end{abstract}

Keywords: corporate social responsibility, sustainable development, safe working conditions, accident, social protection, discrimination of workers' rights, human capital.

\section{INTRODUCTION}

Corporate social responsibility is now an effective tool for sustainable development. If we turn to the interpretation of the concept of "corporate social responsibility," then there is no single approach. Western European countries hold the view that corporate social responsibility is the responsibility of enterprises for their impact on society [1], and in the United States it is "such doing business that meets or even exceeds ethical, legislative and public expectations" [2]. In Russia, this phenomenon is just beginning to develop and is gaining special popularity in large companies, for which corporate social responsibility becomes an important element of doing business.

\section{MATERIALS AND METHODS}

Corporate social responsibility is divided into external and internal. External corporate social responsibility as an instrument of sustainable development is oriented towards the development of the territory where the organization carries out its activities, and includes responsibility to citizens, investors, authorities, public organizations, etc. Internal corporate social responsibility is directed inside the organization and manifests itself directly in the relationship between the manager and employees. Of particular importance here are the social protection measures of workers that the organization is ready to provide. The legislation of Russia defines only the minimum set of measures that the employer must provide to his subordinates. In practice, the implementation of these measures looks different - in each case, the manager, at his discretion, applies them. This is primarily due to the fact that the amount of additional benefits provided to the employee often directly depends on the financial capabilities of the organization. The state, for its part, only establishes measures, but does not finance in any way. Therefore, management may have many desires to expand support measures, but they may not find practical implementation due to various obstacles.

In the early 2000s, whole institutions were established in European countries, the main task of which was to develop and promote the concept of corporate social responsibility in order to achieve such socially significant goals as poverty reduction, vocational training, improvement of the health system, prevention of environmental pollution, rational use of resources [3].

In recent years, most research has shown a direct relationship between corporate social responsibility and the economic success of companies. Organizations with 
a wide range of social activities tend to have higher financial performance. [4]

In Russia, among the main areas of corporate social responsibility are:

1. safety of working conditions;

2. social protection of employees;

3. providing housing for employees;

4. human capital and its development.

\section{DISCUSSION}

One of the most important areas of corporate social responsibility as a tool for sustainable development is the provision of safe working conditions. This is due to the fact that the life and health of workers depends on the implementation of this direction. After all, the life of an employee is the main corporate value of any organization.

The definition of safe working conditions is given in Art. 209 of the Labor Code of the Russian Federation and is interpreted as the absence of exposure of working citizens to harmful and (or) hazardous production factors or as an impact permissible by established standards. At the same time, such production factors are harmful, as a result of which the employee may become ill, and hazardous - production factors, as a result of which the employee may be injured. One of the indicators determining the safety of working conditions in the organization is the number of registered accidents at work. If we proceed from the official data taken from the website of Rosstat for the period from 2012 to 2018 and given in Table No. 1, we can come to the conclusion that in Russia the number of workers affected at work is decreasing every year (including with a fatal outcome). If we take, for example, the indicator of accidents at work with a fatal outcome in 2012 and in 2018, then this indicator in 2012 was 1.82, and already in 2018 - 1.07, i.e. almost twice this indicator became lower. This, of course, is the merit of the employers themselves, who have become more responsible for this area of corporate responsibility at their enterprises.

Among the main causes of accidents at work are:

- absence of clearly regulated organization of works,

- violations during training of employees in labor protection,

- violations by employees of internal labor regulations, etc.

This list can be continued long enough. In this regard, it is important that occupational accidents tend to zero. And here, the measures taken by the employer himself are not enough.

The Russian legislator, in turn, has developed and adopted a number of regulatory acts aimed at assisting in ensuring safe working conditions for workers. Art. 184 of the Labor Code of the Russian Federation establishes a guarantee of providing the employee with payments of compulsory social insurance against accidents that occurred at work. These are temporary disability benefits, insurance payments (lump-sum and monthly), payment of additional costs related to medical, social and professional rehabilitation [5]. In more detail this mechanism is settled by the Federal law of 24.07.1998 No. 125-FZ "About Obligatory Social Insurance from Industrial Accidents and Occupational Diseases".

In this regard, the employer's activities are aimed at creating additional health measures and creating a safe workplace in each particular organization. Among the additional measures applied are:

- maintenance of sanitary and hygienic working conditions,

- health care for employees of organizations and their families,

- timely prevention of occupational diseases,

- provision of medical and rehabilitation measures to the injured employees,

Table 1. Industrial victims in Russia

\begin{tabular}{|c|c|c|c|c|c|c|c|}
\hline & $\mathbf{2 0 1 4}$ & $\mathbf{2 0 1 5}$ & $\mathbf{2 0 1 6}$ & $\mathbf{2 0 1 7}$ & $\mathbf{2 0 1 8}$ & $\mathbf{2 0 1 9}$ & $\mathbf{2 0 2 0}$ \\
\hline $\begin{array}{c}\text { The number of victims of } \\
\text { accidents at work, thousand } \\
\text { people. }\end{array}$ & 31,3 & 28,2 & 26,7 & 25,4 & 23,6 & 23,3 & 20,7 \\
\hline $\begin{array}{c}\text { of them fatal } \\
\text { The number of injured in } \\
\text { industrial accidents per 1000 } \\
\text { people. }\end{array}$ & 1,46 & 1,29 & 1,29 & 1,14 & 1,07 & 1,06 & 0,91 \\
\hline $\begin{array}{c}\text { of them fatal } \\
\text { Number of person-days of } \\
\text { disability in the workplace }\end{array}$ & 1,4 & 1,3 & 1,3 & 1,3 & 1,2 & 1,2 & 1,0 \\
\hline $\begin{array}{c}\text { Spent funds for occupational } \\
\text { safety measures per 1 worker, } \\
\text { RUB }\end{array}$ & 9615,5 & 10930 & 11480 & 12965 & 14246 & 14862,4 & 18825,3 \\
\hline
\end{tabular}


- $\quad$ creation of ergonomic jobs [6],

- $\quad$ prevention of lifestyle change [7].

The next important area of corporate social responsibility as an instrument of sustainable development is the social protection of workers. In this regard, special attention is currently paid to discrimination of workers' rights, including in hiring, paying for work, and career advancement.

The Russian legislator in Art. 3 of the Labor Code of the Russian Federation banned discrimination in the field of labor. Thus, no citizen may be restricted in his or her labour rights or receive any advantages at work, depending on sex, race, nationality, religion, etc. The list of circumstances that are discriminatory is not exhaustive. These can be any circumstances that are not related to the business qualities of the employee. In practice, the provisions of the law prohibiting discrimination by employers are often ignored, especially in the case of women. However, in most cases, acts of courts of general jurisdiction in disputes concerning discrimination against women's rights were not in the latter's favour. Human rights activists confirm that it is almost impossible to win a case of this category. Most often, the courts refuse to satisfy the plaintiffs or, at best, partially satisfy the claims.

There are several types of discrimination in labour relations:

1. Discrimination in the employment and dismissal of employees. The most vulnerable categories of citizens here are disabled people, former prisoners, people of pre-retirement age, pregnant women and women with children, university graduates who do not have work experience.

2. Discrimination in career advancement. This most often applies to women, people with disabilities, immigrants. So, in Russia, it is still not welcome to appoint women to senior positions.

3. Wage discrimination. As a rule, it manifests itself in the fact that workers of equal qualifications and knowledge receive remuneration, the size of which may vary several times. This problem is particularly acute when hiring persons who have just graduated from university and do not have work experience. Their wages are always significantly lower than those of those who have worked in the organization for several/

4. Discrimination in education and training. Organizations welcome graduates of "prestigious" universities, for which employers set higher wages, while those who have graduated from a less "prestigious" university, but who have knowledge and experience, may not receive decent remuneration for their work for a long time.
In practice, persons with disabilities are a particularly vulnerable category of citizens in the workplace. Not wanting to hire them, employers come up with various excuses. For example, in an organization, a disabled person was denied employment because of his low rehabilitation potential. Such refusal of employment was declared illegal by the court. The court argued its position that the refusal of employment due to low rehabilitation potential is far-fetched, is not related to the business qualities of a disabled person, aimed at making excessive claims to him, unrelated to his qualifications and aimed at his exclusion from the number of applicants for a vacant position, which is discrimination in the field of work (Decision of the Verkh-Isetsky District Court of the city of Yekaterinburg from 18.06.2020 N 2-2309/2020).

Legislative measures alone are not sufficient to address discrimination at work. A comprehensive approach is needed here, when, on the one hand, the state is involved to eliminate them, and on the other hand, the employer itself. At the same time, the employee himself should take the initiative, and not "silence" about the facts of discrimination against him. Since in some cases discrimination in the workplace can be most effectively solved at the local level - by contacting employees with their immediate superiors or the head of the organization. In resolving a conflict situation at the workplace, an employee's appeal to a trade union body can also help. If the fact of discrimination of labour rights persists, the employee has the right to apply to other bodies to resolve the conflict situation, in particular, to contact the labor dispute commission. To protect the rights of workers in Russia, the Federal Service for Labor and Employment, labor commissions with territorial bodies in the subjects have been created. For the protection of their violated rights, a working citizen who has been subjected to discrimination can appeal to the court.

One of the most problematic areas of corporate social responsibility as a tool for sustainable development for the organization is the provision of housing for workers. This problem is most acute in modern realities [8]. Since the provision of housing to employees is always associated with significant financial costs of the organization. In the Soviet years, practice was widespread in our country: an employee who worked at the plant for several years could get housing. Currently, the issue of providing housing for workers is realized only through the organization's payment of rent for an apartment rented by an employee, the issuance of loans for the purchase of housing, partial payment of mortgage payments for housing purchased by the employee, and the provision of official housing (dormitories). At the same time, far from every employee, the organization is ready to provide housing. However, the current costs of social and charitable programs reduce current profits, but in 
the long term create a favorable social environment and, therefore, sustainable profits [9].

Human capital and its development are also important areas of corporate social responsibility as a tool for sustainable development. Human capital includes health, knowledge, skills, abilities, motivation, which is possessed by its carrier - a person. Back in 2016, the President of Russia in his Address to the Federal Assembly pointed out that the meaning of the country's policy is the conservation of people, the multiplication of human capital as the main wealth of Russia [10]. In our country, this resource is distributed extremely unevenly and the type of settlement turns out to be one of the most significant parameters not only of the distribution of human capital itself, but also of the return on investment in it [11].

As a rule, the development of human capital in the organization occurs through the education of workers. This is the opportunity to get a higher education (both basic and second), to take monthly courses, short-term trainings, educational internships, distance courses. This is especially important in modern reality, since the predominant level of education in Russia is citizens with secondary special education [12]. The opportunity to increase the level of education is provided by the employer not to every employee, but to those in whom he is interested and who have shown their effectiveness in the workplace. To maintain the professional level of personnel, trainings are organized, relevant literature is written out, special software is bought, access to professional resources is paid. In order to attract talented employees in the field, a number of organizations introduce payments for a healthy lifestyle, pay for visits to fitness centers, trips to sanatoriums, etc

\section{CONCLUSIONS}

Thus, at present in Russia corporate social responsibility as an instrument of sustainable development is still at the stage of development. There is no comprehensive approach at the moment, but more and more heads of organizations are aware of the need to make a contribution to the employee as a person. Since in many respects it is on the person that the development of both the individual organization and the sphere in which it carries out its activities depends. And this already globally affects the level of sustainable development of the country as a whole. In this regard, it is necessary to continue to pay more attention to corporate social responsibility as an instrument of sustainable development, both on the part of the state and on the part of employers themselves, including by developing appropriate local acts, studying and borrowing the experience of "advanced" foreign countries in this direction.

\section{ACKNOWLEDGMENTS}

The authors express gratitude to the Ural State Economic University for the assistance provided in writing the article.

\section{REFERENCES}

[1] E.A. Bryleva, Corporate social responsibility in Russia: the need to form a concept. In: Administrative law and process, 4 (2020) p. 28. DOI: https://doi.org/10.18572/2071-1166-2020-428-31.

[2] Management Models for Corporate Social Responsibility, Jonker Jan, Witte Marcho de. Springer Publishing, 2006, p. 18.

[3] N.A. Gorbunova, Sustainable business development in the aspect of corporate social responsibility. In: New University. Series economics and law, 11-2(69) (2011) p. 31.

[4] J. Margolis, J. Walsh, People and profits? The search for a link between a company's social and financial performance. Mahwah, NJ: Lawrence Erlbaum Associates, p. 58 (2001). DOI: https://doi.org/10.4324/9781410600622

[5] O. Yakovleva, Injuries at work - analysis of disputes on payment for treatment. In: Labor law, 1 (2020) p. 37.

[6] G. A. Dmitrenko, Strategic management: targeted management of the organization's personnel, 2006, p. 115 .

[7] A.G. Vishnevsky, S.A. Vasin, Causes of death and priorities of mortality reduction policy in Russia. In: Economic journal of the Higher School of Economics, 4 (2011) p. 472.

[8] A. Chepurova, Official housing: court disputes. In: Housing law, 8 (2007) p. 69.

[9] I.Yu. Belyaeva, M.A. Eskindarov, Corporate social responsibility: management aspect, 2008, p. 15.

[10] News. URL: https://iz.ru/news/648918.

[11] A. L. Lukyanova, The return on education: what meta-analysis shows. In: Economic Journal of the Higher School of Economics, 14(3) (2010) p. 326.

[12] V.A. Anikin, Human capital in post-crisis Russia: fortunes and returns. In: Journal of Institutional Research, 10(2) (2018) p. 90. 